\title{
The Andrei Scrima Fellowships at the Institute for Ecumenical Research
}

The Andrei Scrima Fellowships at the Institute for Ecumenical Research was inaugurated in the fall of 2017 as a research program aimed at doctoral, postdoctoral and junior researchers in the fields of humanities and social sciences, preference being given to young scholars in the fields of ecumenical, biblical and religious studies. The fellowship program has been motivated by the existence in Sibiu of two well-equipped German language libraries: the library of the Department for History, Patrimony and Protestant Theology, with an emphasis on biblical studies, and the library of the Institute for Ecumenical Research, with a focus on ecumenical studies. Fellows are also encouraged to make the best of their time spent in Sibiu, in its uniquely pluri-confessional environment, and within the research team of the Institute for Ecumenical Research.

The first group of research fellows of the Andrei Scrima Fellowship program at the Institute for Ecumenical Studies have graduated this summer. This year's fellows were: Ionuț Biliuță - researcher at the Gheorghe Sincai Institute for Social Sciences and the Humanities, Târgu Mureș; Marian Pătru - doctoral candidate at the Institute for Orthodox Theology of the Ludwig Maximilian University, Munich; Ionuț Crișan - doctoral candidate at the Andrei Șaguna Theological Faculty, Sibiu; Cătălin Popa Ștefan - currently enrolled in a habilitation project at Philipps-Universität, Marburg; and Cătălin Vatamanu - lecturer at Dumitru Stăniloae Theological Faculty, Iași. The young researchers were awarded grants with durations of one up to ten months based on a research project whose topic falls within the academic scope of the Institute.

The fellows have participated in the activities of the institute by contributing to the Review for Ecumenical Studies (RES), teaching within the Ecumenical Semester, and, most importantly, by conducting research on the theme of their proposed projects. The presentations and subsequent discussions on their research projects have constituted the series of public lectures Andrei Scrima Conferences, among which one can mention here Ex Occidente Lux: Orthodox Students in German Protestant Departments of Theology (Ionut, Biliuță), Sacrificial Spirituality in the Work of Dumitru Stăniloae and Jürgen Moltmann. A Critical Reception for an Ecumenical Theology (Ionuț Crișan), Utopia or Theological-Political Myth? Religion, Politics and Interconfessionality in the Work of Vladimir Solovyov (Marian Pătru). 
Thanks to the generosity of sponsors of the Institute, the Andrei Scrima Fellowship Program will continue for the coming years, with calls for applications being published in October, and the deadline for receiving application scheduled for mid-February each year. After the positive results and reactions received with the completion of this pilot year, the Institute looks forward to welcoming future fellows, both from Romania and abroad.

Antoaneta Sabău, Andrei Scrima Program Coordinator, Institute for Ecumenical Studies, Lucian Blaga University, Sibiu 